\title{
DR. 2554
}

Savannah River Plant Calişornium-252 Shuffler

Software Manual

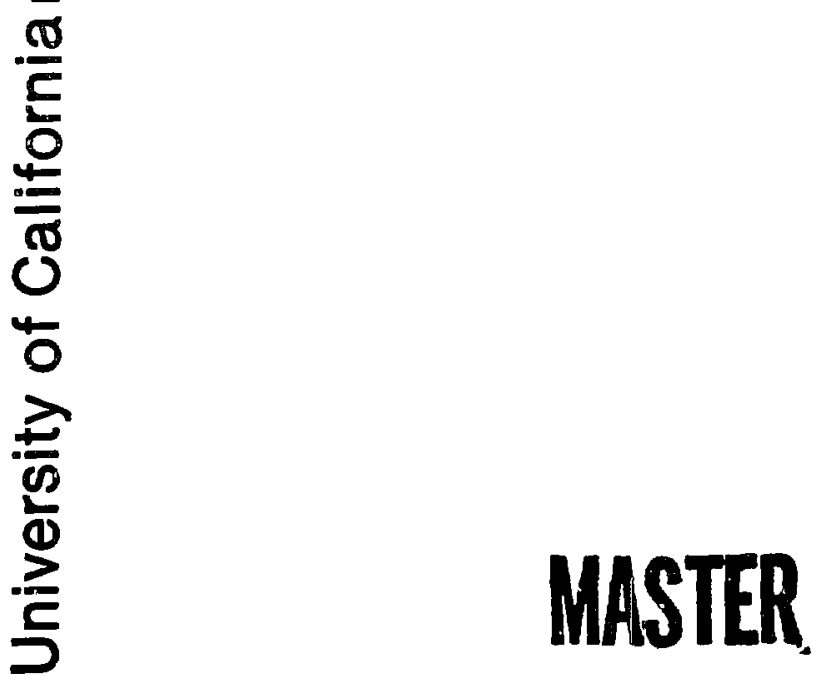


LA-7717-M

Manual

UC-15 and UC-32

Issued: March 1979

\title{
Savannah River Plant Californium-252 Shuffler Software Manual
}

\author{
Susan S. Johnson \\ Thomas W. Crane \\ George W. Eccleston
}

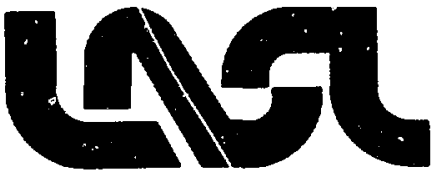


CONTENTS

ABSTRACT ................... . . . . . . .

I. INTRODUCTION . . . . . . . . . . . . . . . . 1

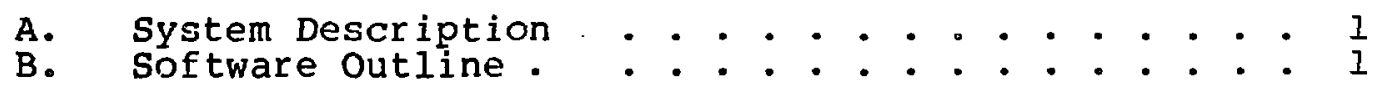

II. OPERATOR'S GUIDE . . . . . . . . . . . . . . . 2

A. Teleray CRT - Special Keys . . . . . . . 2

B. Start-Up Procedure ............... 3

C. Running the ASSAY Program ........... . 4

1. Normal Assay ................. 6

2. Reference Standard ............ 7

3. Calibration ................ 8

D. Running the TEST Program . . . . . . . . . . 9

E. Quick Guide .. . . . . . . . . . . . . . 10

F. Disk File Descriptions .. . . . . . . . . . 11

G. Error Messages ............... . 13

III. SOFTWARE DESCRIPTION . . . . . . . . . . . . . 21

A. Files and Subroutines ............ . 21

B. Program Generation .. . . . . . . . . 30 


\title{
SAVANNAH RIVER PLAN'T CALIFORNIUM-252 SHUFFLER \\ SOFTWARE MANUAL
}

\author{
by
}

Susan S. Johnson, Thomas W. Crane, and George W. Eccleston

February 7,1979

\begin{abstract}
A software manual for operating the Savannah River Plant Shuffler nondestructive assay instrument is presented. The procedures for starting up the instrument, making assays, calibrating, and checking the performance of the hardware units are described. A list of the error messages with an explanation of the circumstances prompting the message and possible corrective measures is given. A summary of the software package is included showing the names and contents of the files and subroutines. The procedure for modifying the software package is outlined.
\end{abstract}




\section{INTRODUCTION}

\section{A. System Description}

The Savannah River Plant (SRP) Shuffler is an instrument designed to perform nondestructive analysis of SRP materials to determine the U-235 content. Operation of this instrument is controlled by a Digital Equipment. Corporation (DEC) LSI-ll microcomputer. The ISI-1l permits simple and concise operation of the Shuffler through FORTRAN and MACRO software developed using the RT-11 diskette-based operating system.

The computer system consists of the LSI-11 microcomputer with $28 \mathrm{~K}$.26-bit words of random access semiconductor memory. The peripheral devices are a Teleray cathode-ray tube (CRT) terminal with a detachable keyboard, an LA-36 DECWriter with keyboard for hardcopy output, and a Data systems dual diskette drive unit to permit storage and retrieval of programs and data. Additional peripherals and interfaces are discussed in the electronics hardware manual and are specific to operation of the shuffler system.

\section{B. Software Outline}

The Savannah Plant Shuffler is operated by a sophisticated software package, consisting of two programs, ASSAY and TEST.

The ASSAY program allows the operator to assay a can to determine its U-235 content. Results from each assay are writter on the data diskeite with the date and sample ID. A second function of the ASSAY program is to allow the operator to calibrate the Shuffler system. To do this, several cans of known U-235 content are assayed and the results are used to calculate fitting parameters. These fitting parameters are then written on the operation diskette and used in subsequent assays. A third function of the ASSAY program is to allow the operator to assay an item and compare it with an assay of the same item done in the past, called the reference standard.

The TEST program allows the operator to test the separate hardware modules which make up the shuffler system in order to diagnose problems. For example, the operator can exercise the individual functions of DMC-10, a stepping motor controller which transfers the source, in order to determine if all functions operate correctly.

Each of the programs is written in FORTRAN and is extensively modularized into FORTRAN subroutines. For example, there is a separate subroutine which handles writing data to diskette and another which reads the dewpoint meter. In addition to the FORTRAN subroutines, there are a number of MACRO (DEC assembly language) subroutines which interface with the hardware modules; all of the subroutines which control a given hardware module are collected together and called a driver. For example, the stepping motor functions are controlled by a driver called DMClo; one of the subroutines in this driver causes an index of the source forward, one causes a jog forward, etc. 


\section{I1. OPERATOR'S GUIDE}

\section{A. Teleray CRT - Special Keys}

RETURN - Sends the command just preceding it to the operating system or to a program which is accepting input. Use this key after typing every command. Also use the RETURN key after following the directions of a PAUSE; this will cause execution of the program to resume. In this guide, the RETURN key will be assumed and not specifically shown.

DEL - Deletes the last character typed. The operating system prints a backslash and the deleted character. when typing resumes a second backslash is printed. For example, the zero was deleted in the line below, making the date 12-OCT-78.

-DATE $10 \backslash 0 \backslash 2-O C T-78$

CTRL U - (Hold down CTRL key at lower left and hit U key.)

This deletes the entire line just typed. The CTRL U must be used before hitting the RETURN key. The operating system responds by typing $a{ }^{\wedge} U$ after the line. For example, the line below was deleted and retyped.

$$
\begin{aligned}
& \text { DATE } 31-\mathrm{SEP}^{\wedge} \mathrm{U} \\
& \text { DATE } 01-\mathrm{OCT}-78
\end{aligned}
$$

BREAK - This interrupts execution of whatever is currently running and brings control to the on-line debugging program called ODT; the presence of ODT is indicated by the a sign on the CRT. To proceed with the program that was interrupted, type $P$ followed by RETURN. (The $P$ will actually print twice on the CRT.)

CTRL C - (Hold down CTRL key at lower left and hit C key.)

This key causes an exit from the program which is currently running. For example, it is the normal method of exit from the compiler FORTRAN when compilation has completed; it then returns control to the operating system. It is NOT the method for normal exit from a user program or an editor. 
S.1 DISKS

S.2 MCDE

S. 3 POWER ON

S.4 BОOT

S.5 DATE

\section{B. Start-up Procedure}

1) Load Shuffler operation diskette in drive 0 (DX0). Insert the diskette so that the labels are on the left face and the arrow is pointing into the drive.

2) Load Data diskette in drive 1 (DXI).

3) Both disk drives should have the WRITE PROTECT switch set to OFF (to the left).

Set MODE switch on the panel to COMPUTER.

1) Teleray Terminal

2) DECW: iter Terminal

3) Bipolar Chopper Driver

4) Electronics rack:

NIM bin, high-voltage units, DMC-10 stepping motor controller, air conditioner, circuit breaker (dirty power), clears power circuit breaker, temperature meter, dewpoint meter, load cells

5) Computer (Power switch is on the LSI-II panel.) Do this step last; it begins the boot procedure. If the switch is oN, cycle it $O F F$ and then $O N$.

1) A dollar sign should appear on the CRT. Type DX followed by RETURN as shown below.* $\$ \mathrm{DX}$

2) The RT-ll monitor should respond RT-11SJ V02C-02C

The period is the signal that the RT-11 monitor is ready to accept the noxt command.

Type the word DATE followed by a space, followed by the current date in the form dd-mm-yy, followed by RETURN, as shown below. The mmm is the first three letters of the month. - DATE 16-OCT-78

If the date is not entered properly, the computer will respond

?DAT?

In this case, just retype the DATE line correctly.

* The (carriage) RETURN is assumed after every line typed and will not be shown. 


\section{Running the ASSAY Program}
A.0 START-UP
Perform the Start-Up Procedure.

A. 1 RUN

Begin execution of the ASSAY program with the followirg command.

\section{- R ASSAY}

A.2 LOAD DISKS The program will then type a reminder to load the data disk and pause.

LOAD DATA DISK IN DXI

PAUSE - THEN HIT RETURN

Verify that the data disk is loaded, then hit RETURN to continue.

A. 3 DATE CHECK

The date entered by the operator during startup is checked for validity. If a date error message is printed, enter the date correctly (see Start-Up Procedure) and go to step A.l. After passing the date check, the number of files on the data disk is given.

A. 4 READ FI'T

Fitting parameters are now read in from the file DXO : FIT.DAT .

A. 5 RFFSTD

The program will now ask if you wish to assay a reference standard. TYpe YES or NO. If YES, continue with the directions in the section called Reference Standard.

DO YOU WISH TO CHECK A REFERENCE?

(YES OR NO) $\rightarrow$ NO

A. 6 COMMANDS

The program will list the possible commands and prompt for the next command.

TYPE H FOR HELP ON KEYBOARD COMMANDS

A - ASSAY

C - CALIBRATION

H - HELP PACKAGE

R - REFERENCE STANDARD CHECK

$\mathrm{X}$ - EXIT

TYPE COMMAND - >

For a normal assay, type $A$ and follow directions in the section called Normal Assay. For a calibration, type $C$ and follow directions in the section called Calibration. 
A. 7 EXTENDED COMPANDS

To gain access to the extended set of commands, type a plus sign (t) in response to the above prompt. The extended list of commands will then be listed out whenever $\mathrm{H}$ is typed. To return to the normal set of commands, type the minus sign $(-)$ in response to the prompt.

The extended commands are:

$$
\begin{aligned}
& \text { B - BACKGROUND MEASUREMENT } \\
& \text { D - DATA READ FROM DISK } \\
& \text { F - FITT ING PARAMETERS FROM KEYBOARD } \\
& \text { G - GET FITTING PARAMETERS FROM DXO } \\
& \text { I - INITIALIZE PARAMETERS } \\
& \text { L - LIST ASSAY DATA } \\
& \text { M - MASS COMPUTATION FROM AN ASSAY } \\
& \text { N - NUMBER OF DISK FILES PND DATE CHECK } \\
& \text { O - OUTPUT ASSAY DATA TO DISK UNIT I } \\
& \text { P - PRINT DELAYED NEUTRON ASSAY RESPONSE } \\
& \text { T - TEMPERATURE MEASUREMENTS } \\
& \text { W - WEIGHT MEASUREMENT }
\end{aligned}
$$

A.8 EXIT

To exit from the ASSAY program, type the letter $X$ in response to the prompt for the next command. TYPE COMMAND $->\mathrm{X}$

The program will respond

EXIT FROM ASSAY 


\section{c. 1. Normal Assay}

N.O START ASSAY

N.I ID'S

N. 2 INSERT CAN

N.3 TEMP \& DEWPOINT

N. 4 WEIGHT

N. 5 BACKEROUND

N.6 COUNTING CYCLES

N.7 TEMP \& DEWPOINT

N. 8 REMOVE CAN

N. 9 ANALYSIS

N.10 DATA TO DISK

N. II SUMMARY
See previous section for how to run the ASSAY program.

The program will request a can j.D and an operator ID. Both can be from 1 to 80 characters in length.

Place can in assay chamber and insert plug. Hit RETURN key when finished. From now until step N.8, the plug interlock is activated and the assay will be aborted if the plug is removed.

The temperature and dewpoint measurements are read.

The weight of the can is measured.

Background measurements are taken. The number of the background cycle is recorded on the CRT. The number of background cycles varies from 6 to 30, depending on how many are necessay to obtain the required precision.

The source is now cycled forward to the irradiation position and back to storage during the delayed-neutron counting. The number of cycles can vary from 6 to 30 .

The temperature and dewpoint measurements are repeated.

once the assay is completed, remove the can.

The response and various errors are now computed. Finally the U-235 content and relative error are computed.

The data from the assay along with the ID's are written on DXI.

A summary block is written out to the terminals showing the ID's, the disk file name, the date, the U-235 content and its two-sigma uncertainty, and the net weight of the item being assayed. 
C. 2. Reference Standard

R. 0 START ASSAY

See the section entitled Running the ASSAY Program. Answer YES to the question DO YOU WISH TO CHECK A REFERENCE?

R.I ENTER STANDARD \# Type the number (1-9) of the reference standard which is to be used for comparison. This is the same digit as the $x$ in the file REFSTD.CDx which holds the reference standard data.

R.2 REFSTD SUMMARY The data from the file REFSTD.00x will be read in and analyzed. A summary will be printed.

R. 3 ASSAY

An assay will be done of the standard. See the section entitled Normal Assay.

R. 4 COMPARISON

The results of the assay and the reference assay will be compared. Messages will indicate whether the responses agree within 4 standard deviations or not. if the responses do not agree, listings will be produced showing all the raw data, first for the assay just completed, then for the reference standard. 


\section{c.3. Calibration}

C. 0 START ASSAY

C. I ENTER MASS

C. 2a ASSAY

C. 2 b DATA ON DISK?
See the section entitled Running the ASSAY Program. Type $C$ to the prompt for the next cominand.

Type the standard's U-235 mass and its one-sigma uncertainty. The program will then print these out and ask for verification that the values are correct. If incorrect, type No and retype them.

The program will then ask if the standard nill be assayed. If so, type YES and perform the assay. (See the section entitled Normal Assay.)

A No answer returns the operator to C.2a. with a YES answer, the system requests the name of the file which contains the calibration data. Type the name of the disk file in the form

$$
\text { DXI:102378.002 . }
$$

NOTE: When this disk file name is typed incorrectly, either the wrong data will be used or the system will abort the ASSAY program if the file is not on the disk. In either case the calibration will have to be restarted. Be VERY CAREFUL!

\author{
C. 3 LISTING \\ C. 4 ANALYSIS \\ C. 5 REPEAT?
}

C. 6 ENTER FUNCTION

C. 7 FITTING

C. 8 FIT TO DISK
You can obtain a listing of the raw data by typing YES to the question LIST ASSAY DAIA?

Totals and a response are computed for this standard.

Answer YES or NO to the question MORE STANDARDS? If YES, repeat steps $C_{0} \perp$ through C. 5 .

The program lists five possible functions to be used in the fit. The first time through, type 1 through 5 for one of these functions. If step $C .7$ has already been done and you are satisfied with the fit obtained, type zero; control will then go to step C.8. 1 isted. Control now goes back to step C.6.

Fitting parameters are written on the file DXO : FIT.DAT.
Fitting parameters are calculatea and 
T.0 START-UP

T. 1 RUN

T.2 REQUEST TEST

T. 3 PERFORM TEST

T.4 EXIT

\section{Running the TEST Program}

Perform the Start-Up Procedure.

Begin execution of the TEST program with the following command.

$$
\text { . } \mathrm{R} \text { TEST }
$$

The TEST program will respond by displaying its valid commands as shown below.

SYSTEM TESTS FOR THE SRP CF-252 SHUFFLER SYSTEM TEST DATE: dd-mmm-YY

$$
\begin{aligned}
& \text { A - ALL TESTS } \\
& \text { C - CLOCK TEST } \\
& \text { D - DMCIO - SOURCE TRANSFER TEST } \\
& \text { E - ELEVATOR AND ROTATION TEST } \\
& \text { H - HELP PACKAGE } \\
& \text { M - MODE TEST } \\
& \text { - PLUG INTERLOCK TEST } \\
& \text { S - SCALER TEST } \\
& \text { T - TEMP AND DEWPOINT TEST } \\
& \text { W - WEIGHT TEST } \\
& \text { X - EXIT }
\end{aligned}
$$

The TSST program will prompt for the test letter. Type the letter followed by RETURN. For example, the mode test was requested below.

$$
\text { TYPE TEST LETTER }->M
$$

To request that all tests be performed, type the letter $A$.

The specific test will acknowledge with a line of output such as

*** MODE SWITCH TEST .

Then follow directions for that specific test. After the test is completed, the TEST program will prompt for the next test.

To exit from the TEST program, type the letter $x$ in response to the prompt for the next test.

TYPE TEST LETTER - > $\mathrm{X}$

The TEST program will respond

EXIT FROM SYSTEM TESTS . 


\section{E. Quick Guide}

POWER

BOOT DX

DATE

DATE 12-OCT-76

ASSAY

R ASSAY

$$
\begin{aligned}
& \text { A - ASSAY } \\
& \text { C - CALIBRATION } \\
& \text { H - HELP PACKAGE } \\
& \text { R - REFERENCE STANDARD CHECK } \\
& \text { X - EXIT }
\end{aligned}
$$

TEST

R TEST

$$
\begin{aligned}
& \text { A - ALL TESTS } \\
& \text { C - CLOCK TEST } \\
& \text { D - DMC-10 - SOURCE TRANSFER TEST } \\
& \text { E - ELEVATOR AND ROTATION TEST } \\
& \text { H - HELP PACKAGE } \\
& \text { M - MODE TEST } \\
& \text { P - PLUG INTERLOCK TEST } \\
& \text { S - SCALER TEST } \\
& \text { T - TEMP AND DEWPOINT TEST } \\
& \text { W - WEIGHT TEST } \\
& \text { X - EXIT }
\end{aligned}
$$




\section{F. Disk File Descriptions}

\author{
DX0 : ASSAY . SAV \\ DX0 : TEST . SAV \\ DX0 : FIT.DAT
}

DX0 : REFSTD.00x

DXI :FILE . LOG
This is the ASSAY program.

This is the TEST program.

This is the file of fitting parameters which is written on DX0: by a calibration run. It is read in each time the ASSAY program is started up, and used in subsequent assay computations. A new calibration run overwrites this file.

This is data produced by an earlier assay. It is used as a reference standard for comparison with a current assay of the same item. The digit $x$ can range from 1 to 9 so that several reference standards can exist.

To put a reference standard on DX0 requires PIP. For example, suppose that the data written on DXI in file 102378.003 is to be used as reference standard number 8 .

$$
\begin{aligned}
& : \text { R PIP } \\
& \star D X 0: \text { REFSTD } .008=D X 1: 102378.003 / X \\
& \star^{\wedge} C
\end{aligned}
$$

If REFSTD.008 previously existed as a file on DX0, it was overwritten.

This file contains information about the data files written on its diskette: the date and sequence number of the most recently written file, and the number of files contained on that disk. This information is used in producing the name of a new data file and in determining if a disk is full.

The ASSAY program requires that FILE.LOG exist on each new data disk, even thcugh the file is empty. The data disks provided by the Los Alamos Scientific Laboratory (LASL) will already contain this file. To write FILE.LOG on a brand new data disk not provided by LASL, use PIP.
.R PIP

$* D \times 1: / 2$

DXI:/Z ARE YOU SURE? YES

${ }^{*} \mathrm{DXI}:$ FILE.LOG $[1]=/ \mathrm{T}$

${ }^{\wedge} \mathrm{C}$ 
DXI : mmddyy •seq

This is a data file produced by an assay. The date is the name of the file, and the sequence number for that date is the file extension. For example, the second file written on October 23, 1978 would be 102378.002. Since the date comes from the date entered by the operator during startup, it is important that the date be entered correctly. 


\section{G. Error Messages}

System error messages are listed in alphabetical order. A short explanation is provided to enhance the meaning of specific error messages that may not be easily understood. The subroutine that issues the message is listed in parentheses followed by $/ T$ or /A to indicate which program, TEST or ASSAY, issues the message.

ASSAY MEASUREMENT ABORTED

REPEAT ASSAY IF SOURCE TRANSFER IS OK.

(ASSAY/A)

The source transfer system is having trouble with the LED positioning sensors. Clean the sensors and check the transfer system with the TEST program.

CLOCK RATE HIGH -- READS XXX IN A 10 SECOND TEST (CTEST/T)

The 1-MHz clock in scaler \#5 is not reading within a set tolerance of the line time clock. Either clock could be in error.

CLOCK RATE LOW -- READS XXX IN A 10 SECOND TEST

(CTEST/T)

See error message above.

DATE TODAY (mm/dd/YY) PRECEDES DATE OF MOST RECENT DISK FILE $(\mathrm{mm} / \mathrm{dd} / \mathrm{YY})$. EITHER ENTER DATE CORRECTLY OR USE A NEW DATA DISK TO AVOID LOSS OF OLD FILES

STOP -- RESTART (DATCHK/A)

The operator entered today's date incorrectly or else the date entered for: previous assays was incorrect.

DIFFERENCE IN RESULT $x \times x$ IS NOT WITHIN 4 SIGMA $x \times x$

AGREEMENT IS WITHIN $\mathrm{x} x \mathrm{X}$ \%

LISTINGS FOLLOW... (COMPAR/A)

The comparison of an assay with a reference standard does not agree. Detailed listings of the raw data for both assays will be printed to aid in locating the reasons for the differences.

$\star \star \star \star \star \star * \star *$ DISK IS FULL $* \star \star \star * * \star \star *$

LOAD NEW DISK IN DXI

PAUSE -- HIT RETURN TO CONTINUE

(FILLOG/A)

The data disk is full (118 files). Insert a new data disk and proceed.

DOOR INTERLOCK BROKEN

$$
\text { (DOOR.MAC/T/A) }
$$

This message indicates that an interrupt has occurred due to the plug interlock being broken during a time when it was enabled, such as the counting cycles in an assay. 
DXI DATA DISKETTE IS NEARLY FULL

SPACE FOR XX ASSAYS REMAINS

(FILLOG/A)

This is a warning that the data diskette is nearly full.

Prepare to load a new data diskette soon.

ENTER DATE CORRECTLY

STOP -- RESTART

(DATCHK/A)

Tre date entered by the operator was incorrect. The ASSAY program must be restarted after the correct date is entered with the DATE command.

?ERR 28 OPEN FAILED FOR FILE

IN ROUTINE XXXXXX LINE $X X$

( $/ A)$

This is a system error message which causes an abort of the program. It occurs because some disk file cannot be opened for reading or writing. If the errcer occurs when a file should be read, it may be that the name of the file was typed incorrectly by the operator or that the file does not exist on the loaded data disk. During writing, this message may occur if the disk is writeprotected.

SRROR IN CREATICN OF DISK FILENAME

(FILLOG/A)

This is an error which should not occur normally. Contact the programmer.

ERROR IN ELEVATOR POWER STATUS

POWER SHOULD BE ON (Or)

POWER SHOULD BE OFF

(RWP.MAC/T/A)

The elevator driver checks the zero crossing relays to ensure that they have applied power or shut off power to the elevator ac motor.

ERROR IN ROTATE POWER STATUS

POWER SHOULD BE ON (Or)

POWER SHOULD BE OFF

(RWP.MAC/T/A)

The table rotation driver checks the zero crossing relays to ensure that they have applied power or shut off power to the rotation ac motor.

ERROR IN SCALER BANK $x$

BIT $\times$ NOT INCREMENTED

(STEST/T)

Scaler test does not read back the same value used to increment the scaler. Bits $1-16$ are tested; low order bit is number 1 . 
ERROR IN STEPPING MOTOR POSITION SENSORS

IRRADIATION LED POSITION FAULTY

CLEAN AND CHECK LED STORAGE SENSORS

CHECK DMCIO AND BIPOLAR CHOPPER DRIVER

THEY MAY BE TURNED OFF

THEN PROCEED WITH YOUR ASSAY WORK

(TXERR/A)

The LED used to position the source for sample irradiation is not blocked when the source is located at the storage position. Replace and clean the sensor holder.

ERROR IN STEPPING MOTOR POSITION SENSORS

STORAGE LED POSITION SENSOR FAULTY

CLEAN AND CHECK LED STORAGE SENSORS

CHECK DMC10 AND BIPOLAR CHOPPER DRIVAR

THEY MAY BE TURNED OFF

THEN PROCEED WITH YOUR ASSAY WORK

(TXERR/A)

The LED used to position the source in the storage position is not unblocked when the source is located at the irradiation position. Clean the sensor and holder.

EXIT CAUSED BY PLUG INTERLOCK BROKEN

(DTEST/T)

The chamber plug was opened in the DMClo test routine. The source is stored and control is returned to the test monitor to prevent a potentially hazardous radiation condition.

FAILURE TO CONVERGE IN SUBROUTINE FIT

$(F I T / A)$

Convergence requires the fractional change in the parameters to be less than one part per 10000 for all parameters when added in quadrature. The U-235 masses for the standards may not have been entered correctly, or the initial parameter guess may have been too far from the best fit value, or one of the parameters has essentially no effect on the fit.

IRRAD NOT DONE - MUST FOLLOW INDEX FORWARD

(DMC10.MAC/T/A)

The irradiation positioning routine was called and the source had not been indexed forward to the irradiation position. This is not allowed. This message should occur only in the TEST program when an operator requests an irradiation position before requesting an index forward. 
IRRADIATION

LED IS NOT SENSING

BLOCKED CONDITION

(DMC10.MAC/T/A)

When the source is located at the storage position, the irradiation LED is blocked. This message indicates that the LED does not sense the block. Clean and check or replace the LED's before continuing.

IRRADIATION

LOCATION NOT REACHED IN 200 JOGS

CLEAN AND CHECK LED'S

(DMC10.MAC/T/A)

Following a forward index, the driver attempts to position the source for irradiation by sersing the irradiation LED. If the distance setting is incorrect, more than 200 jogs could be required to position and this message will result. If the LED is dirty, the positioning might not work. If the driver motor is off, the error would also result.

NO BACKGROUND COUNTS

NIMBIN POWER SUPPLY MAY BE OFF

CHECK SYSTEM BEFORE PROCEEDING

PAUSE -- HIT RETURN TO PROCEED

(BKGND/A)

The first background count cycle (12.2 sec.) was checked and no counts were recorded in any scalers. The power may be off, or for some other reason there is no input to the scaler banks.

NO CYCLE LIGHT SEEN IN 10 SECONDS

TABLE IS NOT ROTATING

(ETEST/T)

The belt connecting the rotate motor to the rotation table may be off the gears. The chamber plug may not be inserted; in this case, the hardware interlock prevents table rotation. Or, the ac power cord for the motors may not be plugged in.

NO ENCODER COUNT'S AFTEE. SOURCE INDEX

IS DMCIO OR BIPOLAR DRIVER POWER OFF?

(DMC10.MAC/T/A)

Prior to an index, the up/down counter in the encoder is zeroed. Following an index, the up/down counter is read and checked. If it is still zero, this message is printed. If the power is on, the connections to the encoder card could be loose or the encoder on the stepping motor could be bad. 
The plug on the chamber was raised or the interlock system was opened during the assay. The source is stored and the assay is aborted to prevent a potentially hazardous radiation condition from occurring.

$\star \star \star * * * * *$ PLUG INTERLOCK BROKEN $\star * \star * * \star * * *$

BACKGROUND MEASUREMENT ABORTED

RESTART IF DOOR IS OK

(BKGND/A)

The background measurement is aborted and the plug interlock must be closed before starting another assay or background measurement.

RADIATION HAZARD POSSIBLE

LET HEALTH PHYSICS CHECK SOURCE POSITION

BEFORE RAISING ASSAY CHAMBER PLUG

(ASSAY/A)

The californium neutron source may have separated from the transfer hardware. A health physics monitor should verify the source position with radiation meters. If the californium is at the assay chamber and the transfer hardware indicates that the source is stored, then the source has separated from the transfer hardware. Personnel experienced in californium handling and knowledgeable in the source coupling design should be contacted to provide advice or assistance in retrieving and reattaching the source. If the health physics monitor has determined that the source is at the storage position, then the assay chamber plug may be 1 ifted and the sample may be removed. With the source at the storage position this error message can be prompted by noise on either flux monitors or delayed-neutron detector banks, a sample with a high neutron emission rate ( $>150000$ neutrons/s), or a sample containing a very large quantity of fissile material. (>20 kg uranium-235).

SCALER BANKS FAIL TRANSFER TEST

(STEST/T)

The counting rate for each of the scaler banks was measured in the background and delayed-neutron counting mode for 30 one-second cycles. If the difference for any bank is greater than four standard deviations for the two counting modes, then the scaler bank fails this test. If the failure occurs in either flux monitor (scalers 0 or $I$ ) and the count rate is low (below 5 counts/s), the situaition is not serious. However, if the failure occurs in the delayed-neutron banks iscalers 2 , 3, or 4), the assays will be biased, and the source of the bias should be eliminated. Fissionable material left in the assay chamber, large changes in the room neutron background, or unusual electrical noise may cause a failure for this test. 
A singular solution requires more mass standards before the fit can be calculated.

STORAGE

LED IS NOT SENSING

UNBLOCKED CONDITION

(DMC10.MAC/T/A)

When the source is located at the irradiation position, the storage LED is unblocked. This message indicates that the LED does not sense this. Clean ard check or replace the LED's before continuing.

STORAGE

LOCATION NOT REACHED IN 200 JOGS

CLEAN AND CHECK LED'S

(DMC $10 . \mathrm{MAC} / \mathrm{T} / \mathrm{A})$

Following a reverse index of the source toward the storage location, the driver attempts to position the source at the LED. If the LED is dirty, it is not possible to position the source accurately. If the power supply is off, the source will not move.

SULCESSIVE INDEX'S NOT ALLOWED IN THE

FORWARD DIRECTION (Or)

REVERSE DIRECTION

(DMC $10 . \mathrm{MAC} / \mathrm{T} / \mathrm{A})$

The stepping motor driver does not allow the source to be indexed successively in the same direction. This prevents damage to the drive system.

SYSTEM IS CALIBRATING

DEWPOINT TEMPERATURE NOT READ

(DEWPT/T/A)

The dewpoint meter automatically goes through a selfcalibration mode, which requires several minutes. During calibration, the dewpoint cannot be measured, and the value -100.0 is assigned to indicate a calibration was occurring.

TABLE ROTATION OR CYCLE LIGHT FAILURE

(WEIGH/T/A)

An attempt to turn on the table rotation and observe the cycle light turn off, then or, and then off failed. The cycle light may require replacement, the rotation motor or drive system may need repair, the canister may have jammed in the assay chamber, the ac power cord to the rotation motor may be disconnected, or the computer may be in the manual mode. Use the front panel controls on the computer or run the TEST program (ETEST) to isolate the problem. This is not a fatal error, and the weight measurement proceeds without using the cycle light and possibly without rotating the table. 
The ACHECK subroutine is taking too much time to determine the precision of the assay counting data. The effect is to increase the cycle timing on the delayedneutron measurements. This is not a fatal exror, but please notify the programmer in charge of the sirstem.

TRANSFER ERROR =: $\mathrm{x}$

STORAGE LED ERROR $=x$

IRRADIATION LED ERROR $=\mathrm{x}$

IS DMCIO AND BIPOLAR CHOPPER DRIVER POWER ON?

CLEAN AIND CHECK LED SENSORS

(DTESTI $/ T$ )

The source transfer system is not able to position the source because the LED's are not sensing blocked and unblocked positions.

If $x=1$, the LED is not properly functioning.

If $x=0$, the LED should be OK. Clean and replace the LED's and run the TEST program to check them for proper operation.

NEIGHT IS JOW...

HAS CAN BEEN PLACED IN CHAMBER?

YES OR NO $\rightarrow$

(WEIGH/T/A)

The weight routine subtracts off the tare weight (rotation table plus can) from the total weight. If the net weight is then less than $100 \mathrm{~g}$, this message is printed to warn that the can may not have been placed in the chamber. 


\section{Note on Errors}

Several errors may occur without producing any messages that can easily lead to their identification. Generally, these errors are a result of a loose connection or an operator action that prevents the system from being able to check for them. If the power cables to the rotation and elevator motors (connected to the rear of the computer) come loose, the turn tables and elevator will not function. The system will go into a wait loop when attempting to weigh a can because the up and down elevator sensors will never each the up or down state. This problem is easily checked by switching the system to manual mode. In manual, if the rotation LED light does not go on when rotation is switched on, or if the weight light does not go on when the elevator button is pushed, then a loose power connection probably exists.

Another error occurs when the chamber plug is left open when attempting to run the elevator or rotation motor. This method of operation is prevented by hardware interlocks. In addition, when the interlock is broken, the table automatically stops rotating and the eievator is raised if it is in the down position.

Familiarity with the system will produce a quick sense of error conditions on the part of the operator. Any additional error conditions should be noted and sent to the programmer in charge for correction and incorporation into system software and manuals when appropriate. 


\section{SOFTWARE DESCRIPTION}

\section{A. Files and subroutines}

The primary program, ASSAY, is used to obtain calibrations and to assay unknown samies. The files which make up the ASSAY program ace the following.

SOURCE

ASSAY . FOR

ANALYS.FOR

UTIL.FOR

DISK.FOR

(various)

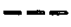

$-\infty$
UTIL.OBJ

OBJECT

ASSAY.OBJ

ANALYS . OBJ

DISK.OBJ

SRPLIB.OBJ

SYSLIB.OBJ

FORLIB. OBJ
FUNCTION

Monitors the assay and background measurements

Monitors the steps in calibration and reduces raw data to obtain U-235 content

Utility routines for temperature, dewpoint, $\mathrm{BCD}$ conversion, and weighing

Disk read and write routines

A library of driver routines

A DEC library of auxiliary subroutines

A DEC library of FORTRAN code

The TEST program allows the operator to run diagnostics on each part of the Shuffler system. TEST is made up of the following files.

SOURCE

TEST.FOR

UTYL。FOR

(various)

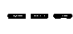

OBJECT

TEST.OBJ

UTIL.OBJ

SRPLIB.OBJ

SYSLIB.OBJ

FORLIB.OBJ
FUNCTIOIN

Monitors the test functions

Utility routines

A library of driver routines

A DEC library of auxiliary subroutines

A DEC library of FORTRAN code 
Table III-I lists the FORTRAN files and the subroutines contained in each file, along with a brief description of each subroutine. Table III-II lists the assembly language drivers along with a brief description of all entry points in each driver. Table III-III lists the contents of the disks provided with the shuffler. The software listings contain extensive comments and should enable the reader to obtain a more detailed understanding of each routine in the system. 
TABLE III - I

FILE AND SUBROUTINE DESCRIPTIONS

\begin{tabular}{|c|c|c|}
\hline $\begin{array}{l}\text { DISK } \\
\text { FILENAME }\end{array}$ & $\begin{array}{l}\text { SUBROUTINE } \\
\text { NAME }\end{array}$ & SUBROUTINE FUNCTION \\
\hline \multirow[t]{10}{*}{ TEST.FOR } & MONITOR & CON'ROLS CALLS TO THE TEST ROUTINES \\
\hline & MTEST & $\begin{array}{l}\text { TESTS THE SETTING OF THE MANUAL/ } \\
\text { COMPUTER MODE SWITCH }\end{array}$ \\
\hline & ETEST & $\begin{array}{lllll}\text { TESTS THE } & \text { SAMPLE } & \text { ROTATION } & \text { MOTOR, } \\
\text { CYCLE LIGHT AND THE } & \text { UP/DOWN ELEVATOR } \\
\text { OPERATION } & & & \end{array}$ \\
\hline & STEST & $\begin{array}{l}\text { THE SCALER TEST INCREMENTS ALL } 6 \\
\text { SCALERS AND CHECKS FOR BIT DROP-OUT } \\
\text { AND INCREMENT ERRORS. } \\
\text { SOURCE TN ADDITION, A } \\
\text { TRANSFER TEST IS MADE TO }\end{array}$ \\
\hline & & $\begin{array}{llll}\text { CHECK FOR ELECTRONIC } & \text { SENSITIVITY } & \text { TO } \\
\text { EITHER THE SOURCE } & \text { IRRADIATION } & \text { OR } \\
\text { TRANSFER. } & & & \end{array}$ \\
\hline & DTEST & $\begin{array}{l}\text { DMCID TEST CHECKS THE SOURCE TRANSFER } \\
\text { SYSTEM. THE INDEX, JOG, AND SOURCE } \\
\text { POSITIONING FUNCTIONS CAN BE 'PESTED } \\
\text { INDEPENDENTLY OR AS A UNIT. THE } \\
\text { SOURCE TRANSFER TIME IS MEASURED. }\end{array}$ \\
\hline & PTEST & $\begin{array}{l}\text { THE PLUG TEST CHECKS THE OPERATION } \\
\text { OF THE CHAMBER DOOR IN'PERLOCK. }\end{array}$ \\
\hline & TTEST & $\begin{array}{l}\text { THE TEMPERATURE } \\
\text { THERMOCOUPLES AND THE READS }\end{array}$ \\
\hline & CTEST & $\begin{array}{l}\text { THE CLOCK TEST CHECKS THE } 1-\text { MHZ } \\
\text { CLOCK IN SCALER CHANNEL 5 AND DETER- } \\
\text { MINES IF IT IS OFERATING WITHIN A } \\
\text { SET TOLERANCE OF THE LINE TIME CLOCK. }\end{array}$ \\
\hline & WTEST & $\begin{array}{l}\text { PHE WEIGHT TEST OU'PPUTS READINGS } \\
\text { FROM THE LOAD CELLS WII' NO WEIGHT } \\
\text { AND WITH A STANDARD OF KNOWN WEIGHT. }\end{array}$ \\
\hline
\end{tabular}


TABLE III-I (cont.)

\begin{tabular}{|c|c|c|}
\hline $\begin{array}{l}\text { DISK } \\
\text { FILENAME }\end{array}$ & $\begin{array}{l}\text { SUBROUTINE } \\
\text { NAME }\end{array}$ & SUBROUTINE FUNCTION \\
\hline \multirow[t]{7}{*}{ ASSAY . FOR } & MAIN & $\begin{array}{l}\text { CONTROLS ALL CALLS TO OPERATE, CALI- } \\
\text { BRATE AND PERFORM MATERIAL ASSAYS }\end{array}$ \\
\hline & INITAL & INITIALIZES SYSTEM PARAMETERS \\
\hline & ASSAY & $\begin{array}{l}\text { PERFORMS THE STEPS REQUIRED TO COM- } \\
\text { PLETE A MATERIAL ASSAY }\end{array}$ \\
\hline & BKGND & $\begin{array}{l}\text { COLLECTS BACKGROUND DATA } \\
30 \text { CYCLES AT } 12.2 \text { SECONDS PER CYCLE }\end{array}$ \\
\hline & COMPAR & $\begin{array}{lccccc}\text { COMPARES } & \text { AN } & \text { ASSAY } & \text { WITH } & \text { A } & \text { REFERENCE } \\
\text { STANDARD } & \text { TO } & \text { VERIFY } & \text { PROPER } & \text { SYSTEM } \\
\text { OPERATION } & & & & \end{array}$ \\
\hline & DATCHK & $\begin{array}{lll}\text { CHECKS } & \text { FOR VALID DATE INFORMATION TO } \\
\text { ENSURE } & \text { THAT NO DISK FILE OVERWRITE } \\
\text { WILL } & \text { OCCUR AND THAT SEQUENTIAL } \\
\text { ASSAYS } & \text { IN TIME ARE RECORDED PROPERLY. } \\
\text { PRINTS NUMBER OF DATA FILES WRITTEN } \\
\text { ON THE DISK. }\end{array}$ \\
\hline & LIST & $\begin{array}{l}\text { OUTPUTS TO THE CRT AND THE LA-36 THE } \\
\text { RAW DATA COLLECTED FROM AN ASSAY }\end{array}$ \\
\hline \multirow[t]{6}{*}{ ANALYS.FOR } & CALIB & $\begin{array}{l}\text { GUIDES THE ASSAY OF STANDARDS TO } \\
\text { OBTAIN A SET OF CALIBRATION DATA }\end{array}$ \\
\hline & PARINP & $\begin{array}{l}\text { READS CALIBRATION FITTING PARAMETERS } \\
\text { FROM DISK FILE DX0:FIT.DAT }\end{array}$ \\
\hline & FIT & $\begin{array}{l}\text { FITS THE ASSAY DATA TO THE CALIBRA- } \\
\text { TION FUNCTION USING THE GAUSS-SEIDEL } \\
\text { METHOD }\end{array}$ \\
\hline & RSPNSE & $\begin{array}{l}\text { CALCULATES THE FITTING FUNCTION } \\
\text { ITS DERIVATIVES AS NEEDED FOR THE } \\
\text { CALIBRATION AND MASS CALCULATIONS }\end{array}$ \\
\hline & MASS & 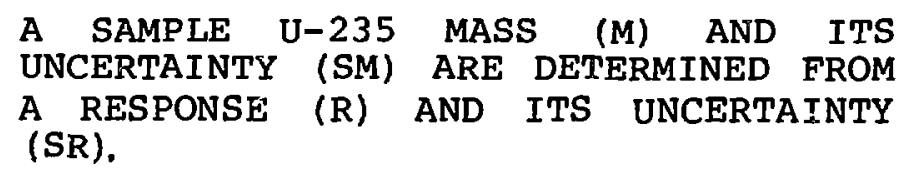 \\
\hline & RESULT & $\begin{array}{l}\text { CORRECTS THE MEASURED DELAYED- } \\
\text { NEUTRON RESPONSE FOR FLUX MONITOR } \\
\text { VARIATIONS AND SAMPLE HEIGHT }\end{array}$ \\
\hline
\end{tabular}


TABLE III-I (cont.)

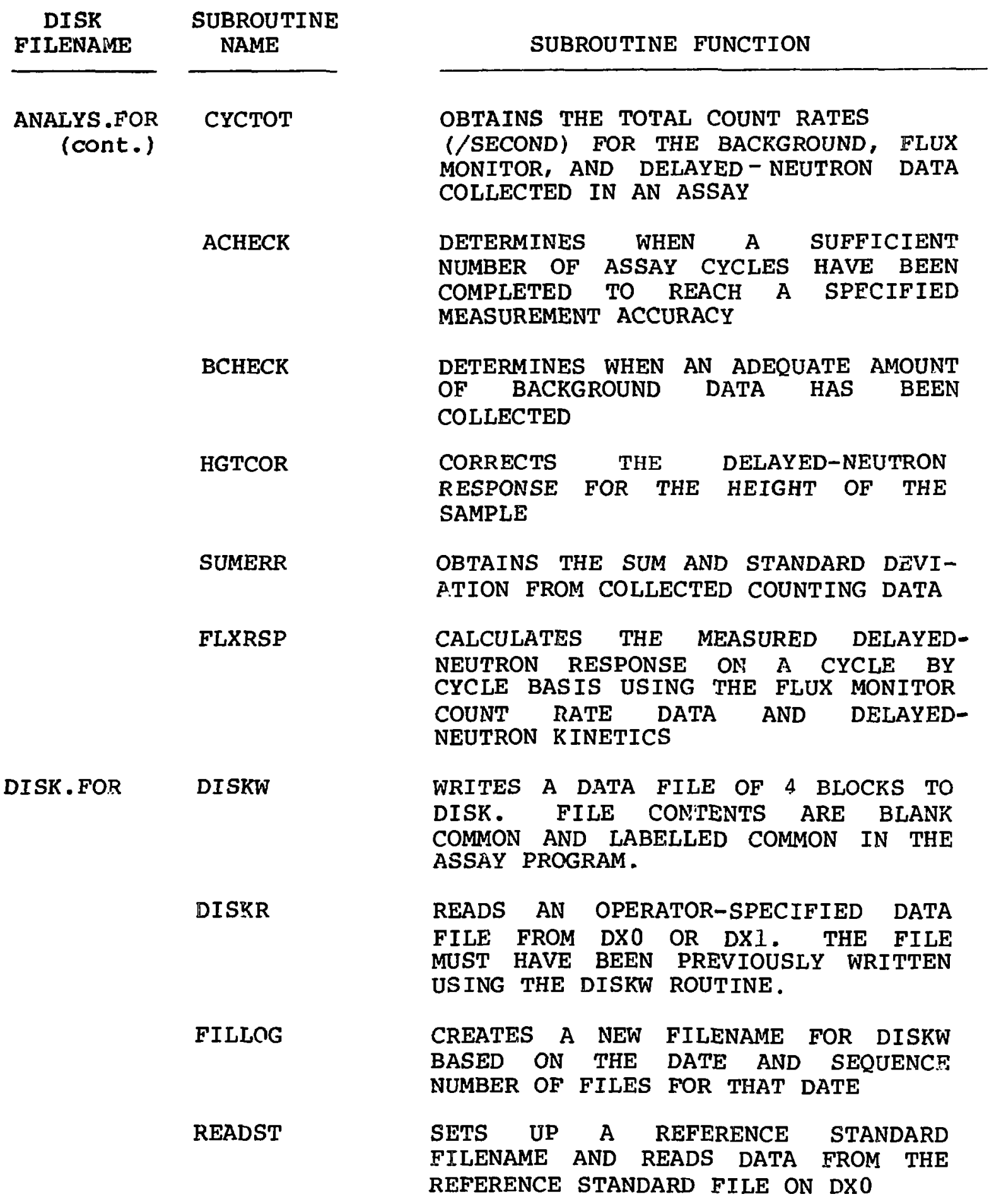


TABLE III-I (cont.)

\begin{tabular}{|c|c|c|}
\hline $\begin{array}{l}\text { DISK } \\
\text { FILENAME }\end{array}$ & $\begin{array}{l}\text { SUBROUTINE } \\
\text { NAME }\end{array}$ & SUBROUTINE FUNC'PTON \\
\hline \multirow[t]{9}{*}{ UTIL.FOR } & TXERR & TRANSFER ERROR ROUTINE OUTPUTS ERROR \\
\hline & & TRANSFER POSITION LED ${ }^{\circ} \mathrm{S}$. \\
\hline & TEMP & THE TEMPERATURE ROUTINE READS THE 3 \\
\hline & & $\begin{array}{l}\text { THERMOCOUPLES, CONVERTS THE BCD } \text { DATA } \\
\text { TO BINARY, AND PLACES THE RESULT INTO } \\
\text { "ITEMP" IN THE COMMON BLOCK. }\end{array}$ \\
\hline & WEIGH & $\begin{array}{llll}\text { THE WEIGH } & \text { ROUTINE READS } & \text { THE } & \text { BCD DATA } \\
\text { FROM THE } & \text { LOAD CELLS. } & \text { THE } & \text { DATA IS }\end{array}$ \\
\hline & & $\begin{array}{l}\text { CONVERTED TO BINARY AND PLACED INTO } \\
\text { "IWEIGH" IN THE COMMON BLOCK. }\end{array}$ \\
\hline & DEWPT & THE DEWPOINT ROUTINE READS THE BCD \\
\hline & & $\begin{array}{l}\text { DEWPOINT DATA AND PLACES } \\
\text { RESULT INTO "IDEWPT" IN }\end{array}$ \\
\hline & CONV & $\begin{array}{lllll}\text { THE CONVERSION } & \text { ROUTINE } & \text { CHANGES } \\
\text { BINARY CODED DECIMAL } & \text { (BCD) } & \text { INFORMA- } \\
\text { TION TO INTEGER BINARY DATA. } & \end{array}$ \\
\hline
\end{tabular}


TABLE III-II

ASSEMBLY LANGUAGE DRIVER ROUTINES

SOURCE FOR EACH DRIVER IS CONTAINED IN A FILE OF

THE SAME NAME WITH EXTENSION .MAC - OBJECT

FILES ARE CONTAINED IN THE LIBRARY "SRPLIB.OBJ".

$\underline{\text { DRIVER }}$

CLGT

DOOR

LTCLK
ENTRY POINTS

CLGT

DORENB

DORDIS

DOOR

CLKENB

CLKDIS

CLKRUN

CLKSET

CLKGO

CLKCHK

CLKWAT

STOD

RTOD

CLKON

CLKOFF

SYSCLK
FUNCTIONS

READS THE CYCLE LIGHT INDICATOR (BIT 4) IN THF. ENCODER CARD (ADDRESS 167764) AND RETURNS AN ON OR OFF INDICATOR

READS THE LIGHT

ENABLES AND DISABLES THE CHAMBER PLUG INTERLOCK. IF TH' PLUG IS OPENED WHEN THE INTERLOCK IS ENABLED, A VECTOR INTERRUPT OCCURS AND SETS IDRFLG $=1$ IN COMMON BLOCK/CDOOR/.

ENABLE PLUG INTERLOCK DISABLE PLUG INTERLOCK INTERRUPT SERVICE ROUTINE

RUNS THE IINE TIME CLOCK (60 HZ) FOR A SPECIFIED AMOUNT OF TIME. THE INPUT TIME VALUES MUST BE INTEGER * 4 WORDS .

ENABLE CLOCK DISABLE CLOCK

RUN CLOCK FOR SPECIFIED TIME SET UP CLOCK COUNTDOWN

START CLOCK COUNTDOWN CHECK COUNTDOWN TIME LEFT

WAIT FOR COUNTDOWN TO FINISH

SET TIME OF DAY

READ TIME OF DAY

START ELAPSED TIME MEASUREMENT

STOP AND READ ELAPSED TIML

RESTORE THE SYSTEM CLOCK 
TABLE III-II (cont.)

DRIVER

MODE

RWP

DMCl0

SCALER
INDFWD

INDREV

JOGFWD

JOGRFV

STORE

IRRAD

SIDLE

SPOS

SCHECK
READS BIT 11 IN THE ENCODER CARD (ADDRESS 167764) AND RETURNS 0 IF THE COMPUTER IS IN MANUAL MODE OR 1 IF IN COMPUTER MODE

READ MODE

THE ROTATE-WEIGH PLATFORM ROUTINE TURNS THE ROTATION TABLE ON AND OFF AND RAISES AND LOWERS THE ELEVATOR TO POSITION THE TABLE FOR WEIGHT MEASUREMENTS.

TURN ROTATION OFF

TURN ROTATION ON

ELEVATOR UP

ELEVATOR DOWN

THE DMCIO STEPPING MOTOR CONTROL PROGRAM TRANSFERS AND POSITIONS THE SOURCE, ATTACHFE TO THE CF-252 TELEFLEX CABLE, AT THE IRRADIATION AND STORAGE LOCATIONS USING POSITIONSENSING LED'S.

INDEX SOURCE FORWARD (TO IRRADIATION) INDEX SOURCE BACKWARD JOG 1 STEP FORWARD JOG I STEP BACKWARD MOVE SOURCE TO STORAGE POSITION SOURCE FOR IRRADIATION IDLE STEPPING MOTOR READ SOURCE POSITION FROM UP/DOWN COUNTER

CHECK THAT SOURCE IS STORED

CONTROLS THE ENABLING, CLEARING, AND READING OF THE SIX SCALERS. THE SIXTH SCALER IS THE 1-MHZ CLOCK.

CSCAL

CLEARS SCALERS 0-5

ESCAL ENABLES DESIGNATED SCALERS

READS 24-BIT DATA FROM ONE SCALER TESTS ALL SCALERS BY INCREMENTING 
TABLE III-III

DISK CONTENTS

DISK

SOURCE MODULE DISK (red)

LISTING MODULE DISK (yellow)

OBJECT MODULE DISK (1 avender)

DEC RT-1I SYSTEM DISK (blue)

CF-252 SHUFFLER OPERATION DISK (olive)
FUNC'PION

THIS DISKETTE CONTAINS THE SOURCE (.FOR AND .MAC) MODULES FOR BOTH THE TEST AND ASSAY PROGRAMS.

THIS DISKETTE CONTAINS THE IISTINGS (.LST) FROM COMPILATION AND ASSEMBLY OF ALL SOURCE MODULES.

THIS DISKETTE CONTAINS THE OBJECT FILES (.OBJ) FROM COMPILATION AND ASSEMBLY OF ALL SOURCE MODULES.

THIS DISKETTE CONTAINS THE DEC RT-1I OPERATING SYSTEM.

THIS DISKETTE CONTAINS THE ABSOLUTE (.SAV; FILES FOR RUNNING THE ASSAY AND TEST PROGRAMS, AND SOME OF THE RT-1I OPERATING SYSTEM SUCH AS THE MONITOR AND PIP. 


\section{B. Program Generation}

This section briefly describes the procedure for making updated versions of ASSAY or TEST using the RT-II Vers. 2C Operating system. It is assumed in the following that the programmer fully understands the use of RT-ll: file manipulation and compressions with PIP, the use of an editor, the use of the FORTRAN compiler and MACRO assembler, and the use of LINK.

1. Assign $\mathrm{DKl}$ as the default disk.

ASS DXI:DK

2. Edit the source code using EDIT or TECO. All FORTRAN modules have the extension FOR; all MACRO modules have the extension MAC.

3. Compile or assemble the source module. For example, the FORTRAN module DISR.FOR would be compiled with the switches shown below.

${ }^{*} \mathrm{DISK}, \mathrm{DISK}=\mathrm{DISK} / \mathrm{W} / \mathrm{U} / \mathrm{L}: 1 / \mathrm{D} / \mathrm{O} / \mathrm{E}$

When space on the diskette is linited, it is necessary to specify block sizes.

*DISK $[80], D T S K[40]=D I S K / W / U / L: I / D / O / E$

The MACRO module CLGT.MAC would be assembled as shown below.

${ }^{*}$ CLGT, CLGT $=$ CLGT

4. Copy all object module(s) onto one disk for linking. SYSIIB.OBJ and FORLIB.OBJ should be on the RT-11 system Disk (DXO). Below is the LINK command for ASSAY and TEST.

*ASSAY $[100]$, ASSAY [50] =ASSAY, ANALYS,DISK,UTIL ,DX0 : SYSLIB , DXI : SRPLIB/F

*TEST [100],TEST[50]=TEST, UTIL, DX0 : SYSLIB ,DX1 : SRPLIB/F

5. Copy the new SAV file to the shuffler operation Disk.

6. Reassign DK to DXO before running ASSAY or TEST. ASS DX0:DK 